\title{
25 Research Soure \\ Factors Driving Wetland Herbs Distribution Range of Lake-Terrestrial Ecotone in Tibet, China
}

Peiru Zheng

Chinese Research Academy of Environmental Sciences https://orcid.org/0000-0001-5002-8296

Chunhua LI

Chinese Research Academy of Environmental Sciences

Chun YE ( $\nabla$ yechbj@163.com )

Chinese Research Academy of Environmental Sciences https://orcid.org/0000-0001-5926-2708

Hao Wang

Chinese Research Academy of Environmental Sciences

Weiwei Wei

Chinese Research Academy of Environmental Sciences

\section{Ye Zheng}

CRAES: Chinese Research Academy of Environmental Sciences

Xiangyong Zheng

Wenzhou University

Research

Keywords: Lake-terrestrial ecotone, Moving split-window technology, Wetland herbs, Tibet lakes

Posted Date: December 1st, 2021

DOI: https://doi.org/10.21203/rs.3.rs-1078363/v1

License: (c) (1) This work is licensed under a Creative Commons Attribution 4.0 International License.

Read Full License 


\section{Abstract}

Background: Lake is a critical part of Tibet's hydrological cycle, the lake-terrestrial ecotone is the most sensitive area in the water and terrestrial ecosystem. For the ecological protection and maintenance of the lakeside zone, defining the upper boundary of the lake-terrestrial ecotone is a key issue that needs to be solved urgently. However, the ecological characteristics of lake-terrestrial ecotone made it diffcult to delimit. Wetland herbs are characteristic plants of the radiant belt toward the land of the lake-terrestrial ecotone, and their distribution range can be used to reflect the upper boundary of the lake-terrestrial ecotone. We took Baksum Lake, Yambdroktso, Namtso, Siling Co as examples, based on the spatial structure of the lake-terrestrial ecotone, used the moving split-window technology (MSWT) delimited the range of wetland herbs.

Results:The results of MSWT showed the distribution range of wetland herbs in each lake-terrestrial ecotone with the natural-wetland type sampling line of Baksum Lake, Yambdroktso, Namtso, Siling Co was $51 \mathrm{~m}, 56 \mathrm{~m}, 33 \sim 53 \mathrm{~m}, 19 \sim 31 \mathrm{~m}$. DCA showed number of wetland herbs species,BK1区YT1=NT1区NT2】 SC1=SC2. PCA, RDA showed SMO, pH, SSC, and soil nutrient content had obvious correlation with distribution range.

Conclusion:MSWT was a feasible method to delimit the distribution range of wetland herbs. SMO, $\mathrm{pH}$, SSC, and soil nutrient content were all-important environmental factors affect the wetland herbs distribution range of the four lakes, however, the SMO was the most important factor. Besides, compare with the lakes in the lower Yangtze Plain,the high-density population distribution,high-intensitive human activity invaded the plants' growth area, resulting in a smaller distribution range.

\section{Background}

Lake-terrestrial ecotone is an important part of the lake ecosystem. It has the functions of intercepting pollutants carried by surface overflow, runoff, and underflow; providing habitat for wild animals, and improving the ecological diversity of lakes[1]. Due to the "living by water" history, lake-terrestrial ecotone is the most susceptible part of lake ecosystem. For economic development, flood protection, tourism, and other purposes, people has carried out high-intensity and unreasonable development in lake-terrestrial ecotone, causing the lake-terrestrial ecotone ecosystem to be strongly disturbed, inducing or accelerating its ecosystem degradation[2]. With the increasing awareness of the necessity of ecological environment protection, large quantities of ecological restoration works have implemented on lake-terrestrial ecotone[3-9]. Natural-wetland type lake-terrestrial ecotone(Fig. 1) is the target and template of ecorestoration. The range delimitation is the primary and crucial task in lake-terrestrial ecotone protection and restoration. The typical feature of natural-wetland type lake-terrestrial ecotone is the change of vegetation, which is mainly manifested in the transition from wet plants to mesophytes and xerophytes. Because they are very sensitive to soil moisture changes, the distribution range of wet plants can be used to reflect the boundary of lake-terrestrial ecotone[1]. According life forms, wet plants can be divided into trees, shrubs, and herbs, compared with trees and shrubs that can absorb water and nutrients from 
deeper soil, herbaceous plants are more sensitive to soil moisture changes[10], can be better reflected the boundary. Therefore, how to accurately delimit the distribution range of wetland herbs in the laketerrestrial ecotone with natural-wetland type has become an urgent problem to be solved.

Moving Split-Window Technology(MSWT) is widely used to delimit the boundaries of the chemical or physical characteristics of soil and the boundaries of vegetation or animal communities[11-14].MSWT can eliminate errors caused by sampling deviations of individual samples and can reflect the position and width of the ecotone more objectively than other methods[15]. Nowadays, MSWT become the most widely used and most effective method for analyzing the boundaries of ecotone[16]. Researchers have used MSWT to accurately delimit the range and boundaries of vegetation or animal communities and soil nutrient content[17-25]. Therefore, this study selected MSWT to delimit the boundary of the wetland plant-mesophyte/xerophyte transition zone and use this boundary as the upper boundary of the laketerrestrial ecotone with natural-wetland type.

The distribution of herbaceous plants is affected by the combined effects of different environmental factors. Lake-terrestrial ecotone is a relatively small spatial scale. Compared with climate factors, factors such as micro-topography, soil physical and chemical environment and hydrological are the main affecting factors[26]. Topographic and geomorphological factors (altitude, slope) affect the spatial redistribution of solar radiation, surface water distribution[27], and influence the growth and distribution of wet plants. Therefore, compared with other environmental factors, soil physical and chemical conditions (soil type, soil nutrient, soil moisture, $\mathrm{pH}$, salinity, etc.) directly affect the distribution of wet plants[28-30]. To protect and restore the lake-terrestrial ecotone, research the wet plant biodiversity, distribution characteristics, and influencing factors will help clarify the relationship between wetland plant distribution range and lake-terrestrial ecotone habitat factors. Predicting the dynamic changes in the spatial range of lake-terrestrial ecotone, revealing the formation mechanism of the distribution pattern of wetland plants and the ecological process of community succession and its internal mechanism, which play a greatly significant part in lake protection and restoration.

Tibet Plateau is the area that has the most lakes in China. According to statistics, there are more than 1,500 lakes in Tibet, most of which are salt lakes[31], and more than $97 \%$ are inland lakes[32]. According to the distribution characteristics of river systems and lakes, the lakes in Tibet can be divided as the outflow lake area in southeast Tibet; the outflow-inland lake area in southern Tibet; the inland lake area in northern Tibet. Lakes play a key role in the hydrological cycle in Tibet and greatly affect the regional climate, water resources, terrestrial and aquatic ecosystems[33]. The lakes in Tibet are located at high altitudes and extreme climatic conditions and are less affected by human activities. Natural-wetland is the main type of lake-terrestrial ecotone. However, in recent years, with the mining of minerals[34], the amount of livestock breeding has increased[35], and the construction of roads and railways[36] have strongly disturbed the lake-terrestrial ecotone ecological environment in Tibet. In addition to human disturbance, the change of lake water level also has a certain impact on the ecological environment of lake-terrestrial ecotone. For example, the expansion of the lake area in Siling Co led to the degradation of alpine grasslands and meadows in the lake area[37-38]. The lake ecosystem in Tibet is very sensitive to 
human and natural disturbances, and once damaged, it may never repair[39-40]. Moreover, as the highest altitude area in the world, the wet harbors plants which are cold-tolerant, salt-tolerant, can survive extreme climatic conditions and have strong regional representation. Therefore, to protect the Tibet lakes, delimiting the distribution range of wetland herbs of lake-terrestrial ecotone and their influencing factors are of great significance to the protection of Tibet lakes.

The representative lakes Baksum Lake from the outflow lake area in southeastern Tibet, Yamdroktso from the outflow-inland lake area from southern Tibet, and Namtso and Siling Co lakes from the inland lake area of northern Tibet were selected in this study. Used MSWT to delimited the distribution range of wetland herbs of lake-terrestrial ecotone. To explain the environmental factors which influenced the herbaceous plant distribution, we surveyed the Average annual temperature (AAT), Average annual rainfall(AAR), altitude, slope, soil characteristics. Researched the relationship among environmental factors, wetland herbs species composition and community diversity index to determine the main influencing factors of the wetland herbs distribution range.

\section{Materials And Methods}

\section{Study Areas}

The representative lakes Baksum Lake from the outflow lake area in southeastern Tibet, Yamdroktso from the outflow-inland lake area from southern Tibet, and Namtso and Siling Co from the inland lake area of northern Tibet were selected in this study.

Baksum Lake $\left(30^{\circ} 0^{\prime} 1{ }^{\prime \prime} \mathrm{N} 30^{\circ} 2^{\prime} 53^{\prime \prime} \mathrm{N}, 93^{\circ} 53^{\prime} 37^{\prime \prime} \mathrm{E} \sim 94^{\circ} 1^{\prime} 48^{\prime \prime} \mathrm{E}\right)$ is located in the southeast of the Qinghai-Tibet Plateau. The elevation of the lake is about $3480 \mathrm{~m}$, the total area of the lake is $26 \mathrm{~km}^{2}$, and the maximum depth is about $120 \mathrm{~m}$. The average annual temperature in the lake area is around $6.0{ }^{\circ} \mathrm{C}$, and the average annual precipitation is $600-700 \mathrm{~m}$. An open freshwater lake with a lake $\mathrm{pH}$ of about 7.2[41].

Yamdroktso $\left(8^{\circ} 27^{\prime} 00^{\prime \prime} \mathrm{N} \otimes 29^{\circ} 12^{\prime} 00^{\prime \prime} \mathrm{N}, 90^{\circ} 08^{\prime} 00^{\prime \prime} \mathrm{E} \otimes 91^{\circ} 45^{\prime} 00^{\prime \prime} \mathrm{E}\right)$ is surrounded by high mountains, the lake is $4441 \mathrm{~m}$ above sea level, and the total area is $638 \mathrm{~km}^{2}$, the water depth is $20-40 \mathrm{~m}$, and the pH value of the lake is about 9.2-9.3. It is one of the largest closed inland saltwater lakes in southern Tibet[42]. The annual average temperature is $2.4^{\circ} \mathrm{C}$, and the annual average precipitation is $373.0 \mathrm{~mm}[43]$.

Namtso ( $\left.30^{\circ} 30^{\prime} 00^{\prime \prime} \mathrm{N} \varangle 30^{\circ} 55^{\prime} 00^{\prime \prime} \mathrm{N}, 90^{\circ} 16^{\prime} 00^{\prime \prime} \mathrm{E} \otimes 91^{\circ} 03^{\prime} 00^{\prime \prime} \mathrm{E}\right)$ is located between Lhasa City and Nagqu City. Lake The area is $2020 \mathrm{~km}^{2}$, and the lake surface is $4718 \mathrm{~m}$ above sea level[44]. The climate difference between the lake areas on both sides of Namtso, the annual average temperature on the north bank of Namtso is $0.4{ }^{\circ} \mathrm{C}$, the annual average rainfall is $301.2 \mathrm{~mm}$, the annual average temperature on the south bank is $1.3^{\circ} \mathrm{C}$, and the annual average rainfall is $486.9 \mathrm{~mm}[45]$. The $\mathrm{pH}$ value of the lake is $7.8-9.5[46]$, which is a typical inland saltwater lake on the plateau.

Siling Co $\left(31^{\circ} 34^{\prime} 00^{\prime \prime} \mathrm{N}-31^{\circ} 51^{\prime} 00^{\prime \prime} \mathrm{N}, 88^{\circ} 33^{\prime} 00^{\prime \prime} \mathrm{E}-89^{\circ} 21^{\prime} 00^{\prime \prime} \mathrm{E}\right)$ is the largest lake in the Tibet Autonomous Region. The lake is $4,530 \mathrm{~m}$ above sea level and the maximum depth is about $50 \mathrm{~m}$. The climate in the 
lake area is mostly in the plateau sub-frigid zone, with a semi-arid climate as the main[47]. The multi-year average temperature is $0.2{ }^{\circ} \mathrm{C}$, the annual precipitation is $290-321 \mathrm{~mm}$ [48], and the lake water $\mathrm{pH}$ is 9.49.7(Chen 2001).

Conducted field surveys on the above lakes, Conducted on-site investigation and sampling of points that meet the conditions of lake-terrestrial ecotone on natural-wetland type, starting from the lake's multi-year average high water level line and extending to the land area. Totally, six sampling lines were set up in four lakes, and the starting points of each sampling line are shown in Fig.2.

\section{Delimite Range Method}

Used the moving split-window technology(MSWT) delimited the distribution range of wetland herbs. The principle of MSWT is to divide a segmentation window into two half windows, $A$ and $B$, by calculating the difference coefficient between $A$ and $B$, and then move down one point in order, and then calculate the difference coefficient, until every quadrat on the sample strip participates in the calculation (Fig. 3)[50-51]; In this study, Used the distance coefficient as the ordinate and the sample number as the abscissa. The peak value generated by the drawing was expressed as the location of the hygroscopic and mesophytic/xerophyte herbaceous transition zone in the lake-terrestrial ecotone, and the peak width was expressed as the range of this transition zone. The endpoint of the peak width was the boundary between the transition zone and the adjacent ecosystem[19]. The distance from the endpoint of the peak width to the start point of the sample line was the distribution range of wetland herbs in the lake-terrestrial ecotone. used Squared Euclidean Distance (SED) as the distance coefficient and important value (IV) as the calculation index.

SED calculation formula囚

$$
\operatorname{SED}_{n}=\sum_{i=1}^{m}\left(\bar{X}_{i A}-\bar{X}_{i B}\right)^{2}
$$

In the formula, SEDn represents the squared euclidean distance when the window is $n, A$ and $B$ are two adjacent windows when the window is $n$, and are the average values of $A$ half-window and $B$ half-window when the parameter is $i(i$ represents the important value of the sampling quadrat), $m$ is the number of window variables, and $\mathrm{n}$ is the window width.

IV calculation formula》

$$
\mathrm{IV}_{a}=\left(\frac{D_{a}}{\sum D}+\frac{C_{a}}{\sum C}+\frac{F_{a}}{\sum F}\right) \times 100 \times \frac{1}{3}
$$

In the formula, represents the important value of species an in the quadrat, represents the density of species an in the quadrat, represents the sum of the density of all plant species in the quadrat, represents the coverage of species an in the quadrat, represents the sum of the coverage of all plants in the quadrat, 
represents the frequency of species an in the quadrat, and represents the sum of the frequencies of all plants in the quadrat.

\section{Sampling Design}

Selected the points of Baksum Lake (BK), Yamdroktso (YT), Namtso (NT), and Siling Co (SC) that meet the conditions of the lake-terrestrial ecotone with nature-wetland type for on-site investigation. Consulted and recorded AAR and AAT of each lake. Set the sampling line with the high water level as the starting point; took wetland herbs as the survey object. On each sampling line, set a $1 \mathrm{~m} \times 1 \mathrm{~m}$ herb quadrat at equal intervals, and number the quadrats until there are no wetland herbs in the quadrat, stop the quadrat layout (Fig. 4). Recorded the name, several species, density, coverage, and frequency of each species in the quadrat, which were used to calculate important values, plant community richness, plant community diversity index, etc.; the on-site measurement of the altitude and slope of the lake-terrestrial ecotone, the surface layer $(0-15 \mathrm{~cm})$ soil in the quadrat was collected to determine soil pH, soil moisture (SMO), soil salt content (SSC), soil organic matter (SOM), soil total carbon (STC), and total soil nitrogen (STN), soil total phosphorus (STP).

\section{Environmental Parameters}

GPS was used to record the elevation and slope of each lake-terrestrial ecotone with nature-wetland type sample line; the surface soil $(0 \sim 15 \mathrm{~cm})$ in the quadrat was collected by the ring knife method, and the soil sample was brought back to the laboratory for cold storage. SMO was determined by the drying method. The soil was dried to a constant weight at $(105 \pm 5){ }^{\circ} \mathrm{C}$, and the water content was calculated based on the difference in the quality of the soil samples before and after drying; the SSC was measured by the conductivity method: soil pH was measured by potentiometric method (the water-soil ratio was 2.5:1); SOM was measured by low-temperature external heating potassium dichromate oxidation-colorimetric method[52]; STC and STN were measured by EA3000 elemental analyzer; STP was determined by The Standards, Measurements and Testing Programme (SMT) method.

\section{Date Analysis}

MSWT was used to quantitatively delimit the distribution range of wetland herbs in each lake-terrestrial ecotone sampling line; principal component analysis (PCA) was used to analyze the main environmental factors that affect the distribution range of wetland herbs; detrended correspond analysis (DCA) was used to reflect the types of wetland herbs in each sampling line, redundancy analysis (RDA) was used to analyze the response relationship between environmental factors and plant diversity index. PCA, DCA, RDA was calculated using CANOCO 5.0.;Origin 8.0 was used for Data analyseing and figtures ploting.

\section{Results And Discussion}

\section{Results}


A total of six lake-terrestrial ecotones with nature-wetland type were selected from four lakes, and 1011 $\mathrm{m} \times 1 \mathrm{~m}$ quadrats were investigated on site. A total of 33 wetland herbs were investigated, belonging to 21 Branches. The four lake-terrestrial ecotone wetland herbs are mainly composed of Rosaceae, Ranunculaceae, and Polygonaceae, with 4 species (accounting for $12.12 \%$ of the number of species), 3 species (accounting for $9.09 \%$ of the number of species), 3 species (accounting for $9.09 \%$ of the number of species). The vegetation coverage of the BK1, YT1, and NT1 was relatively high, with vegetation coverage ranging from $65 \%$ to $95 \%$, and most of the above-mentioned plants were also distributed here. The result of DCA analysis (Fig. 5) showed that BK1, YT1, NT1, NT2, SC1, SC2 had 23, 9, 9, 7, 3, and 3 wetland herbs, respectively. The NT2, SC1 2 had relatively poor climatic conditions, fewer wet herb species, species richness, and community diversity indexes were significantly lower than BK1, YT1 (Fig. $6)$. In the field survey of SC1 2, found that the wetland herbs of these 2 sampling lines were mainly Suaeda glauca and Achnatherum splendens, and the vegetation coverage was about 1\%-18\%.

\section{Characteristics of Environmental Factors and Plant Diversity Index af Each Lake-Terrestrial Ecotone Sampling Line}

The content of AAT ,AAR, elevation, slope, soil pH, SMO, SSC, SOM, STC, STN and STP of each laketerrestrial ecotone sampling line are shown in Fig. 7. The slopes of the 6 sampling lines were not much different in 1 3\%, except for BK1, the other five lines were close in elevation; AAT, AAR, soil moisture and nutrient content of BK1, YT1, NT1 were significantly higher than NT1, SC1 2 ; soil pH and SSC of NT1, SC1 2 were significantly higher. The climate and environmental factors (AAT, AAR), SMO, and soil nutrient conditions of the BK1 were the best among six sampling lines, and were more suitable for wetland herbs growth, therefore,the wet herb coverage, species number, community diversity index and community richness index of BK1 was the highest.

\section{The result of the distribution range delimitation of lake-terrestrial ecotone wetland herbs}

The selection of the width of the MSWT window had an extremely important influence on the accuracy of the delimitation result. Choosing a too-small window width will cause multi-peak interference[53], and too large will weaken the peaks[54]. Therefore, when using MSWT to delimit the distribution range of wetland herbs, it was the most important to determine the optimal window width of each sampling line for calculating SED. Took BK1 sampling line as an example (Fig. 8), took 4, 6, 8, 10, 12 sampling quadrats as the window width respectively, when the window width was 10-12 sample squares, no peak appears; When the window width was 4 to 8 plots, an obvious peak occurs near quadrat 10. Due to the edge effect, the ecotone had a larger species diversity and community richness index than adjacent communities[55], so the appearance of this peak indicated that the plant community at this location had the greatest heterogeneity, and the ecological pattern of the plant community had changed here, it was the location of the ecotone. Based on the field survey, found that the obvious peak showed the area was the BK1 wetmesophyte/xerophyte transition zone. This showed that when the MSWT window width was 4 8 sampling quadrats, it can better reflect the position of the plant transition zone, compared to the window width of 6-8 sampling quadrats, the peaks produced by the window width of the 4 sampling quadrats 
were the most obvious, and the peak width is narrower, which was the optimal window width for BK1 (Fig. 8).

Similarly, used the above method of selecting the most suitable window width to determine the most optimal window width of YT1, NT1, NT2, SC1, SC2 were 4 sampling quadrats(Fig. 9(a)); 4 sampling quadrats (Fig. 9(b)), 6 sampling quadrats (Fig. 9(c)); 6 sampling quadrats (Fig. 9(d)), 4 sampling quadrats (Fig. 9(f)). Under the optimum window width of each sampling line, the wave peak was obvious, the peak value was higher, and the peak width was small, indicating that the MSWT was a feasible method, moreover, wetland herbs of various sampling lines had different distribution ranges.

Combined with the field survey, Baksum lake took the BK1 sampling line as an example. This sampling line was set up $1 \mathrm{~m} \times 1 \mathrm{~m}$ sampling quadrat every $4 \mathrm{~m}$, and a total of 17 sampling quadrats were set up. Quadrat 1-11 were mainly distributed in Commelina diffusa, Potentilla anserina, Plantago depressa, Ranunculus tanguticus, Selaginella nipponica, Duchesnea indica, Salvia rzewalskii and many other wetland herbs. Quadrat 12-17 mainly contained mesophytic and xerophytic herbs such as Aristida triseta, Tripogon chinensis, Gueldenstaedtia verna, Origanum vulgare L., etc. Took the YT1 sampling line as an example of Yamdroktso. The sampling line was set up $1 \mathrm{~m} \times 1 \mathrm{~m}$ sampling quadrat every $4 \mathrm{~m}$, and a total of 16 sampling quadrats were set. Quadrat 1-12 was mainly distributed with Potentilla anserina, Ranunculus tanguticus, Plantago depressa, Aster tataricus, Polygonum sibiricum, and other wetland herbs. Quadrat 13-16 mainly contained mesophytic and xerophytic herbs such as Oxytropis bicolor, Elymus dahuricus, and gray Mesophytic and x xerophytic herbs such as Cyananthus incanus, Artemisia younghusbandii, and Tripogon chinensis, etc. Took the NT1 sampling line as an example of Namtso. The sampling line was set up $1 \mathrm{~m} \times 1 \mathrm{~m}$ sampling quadrat every $3 \mathrm{~m}$, and a total of 17 sampling quadrats were set. Quadrat 1-14 were mainly distributed with Ranunculus tanguticus, Selaginella nipponica, Gentiana pseudoaquatica, Potentilla reptans and other wetland herbs. There were drought-tolerant xerophytic herbs such as Potentilla bifurca L., Tibetia himalaica, Eriophorum comosum, Dysphania aristata, etc in quadrat 14-17.Took SC1 sampling line as an example of Siling Co. The sampling line was set up $1 \mathrm{~m} \times 1 \mathrm{~m}$ sampling quadrat every $5 \mathrm{~m}$, and a total of 15 sampling quadrats were set. Quadrat 1-6 were mainly distributed in salt-tolerant wetland herbs Achnatherum splendens and Suaeda glauca, quadrat 7-15 were mainly distributed xerophytes, Tripogon chinensis, and wet shrubs, Kalidium foliatum. This showed that using MSWT to delimit the distribution range of lake-terrestrial ecotone wetland herbs was the same as the field survey wetland herbs community distribution boundary, and MSWT had good applicability for the division of different community vegetation zones, indicating that MSWT can accurately delimit the growth boundary of wetland herbs[19], therefore, it is feasible to use MSWT to delimit the distribution range of lake-terrestrial ecotone.

The wetland herbs distribution ranges of lake-terrestrial ecotone with the natural-wetland type of Baksum Lake, Yamdroktso, Namtso, and Siling Co were shown in Table 1 and Fig. 10, which were 51 m, 56 $\mathrm{m}, 33 \sim 53 \mathrm{~m}, 19 \sim 31 \mathrm{~m}$.

Table 1 Range of hygroscopic herbours plants distribution of lake-terrestrial ecotone on different lines 


\begin{tabular}{lllll} 
Lake & Sampling line number & $\begin{array}{l}\text { Quadrat spacing } \\
\text { /m }\end{array}$ & $\begin{array}{l}\text { Peak width } \\
\text { end quadrat }\end{array}$ & $\begin{array}{l}\text { Range } \\
\text { /m }\end{array}$ \\
\hline Baksum Lake & BK1 & 4 & No.11 & 51 \\
\hline Yambdroktso & YT1 & 4 & No.12 & 56 \\
\hline Namtso & NT1 & 3 & No.14 & 53 \\
\cline { 2 - 5 } & NT2 & 3 & No.9 & 33 \\
\hline Siling Co & SC1 & 5 & No.6 & 31 \\
& SC2 & 5 & No.4 & 19
\end{tabular}

\section{Factors affecting the distribution and diversity of wetland herbs}

Used PCA to identify the most important environmental factors affecting the distribution range of wetland herbs, It can be seen from Fig. 11that the Shannon-Wiener index(SW), Marglef index(M), SMO, soil $\mathrm{pH}$, and SSC were the most important factors affecting the distribution of wetland herbs. ShannonWiener index and Marglef index were the main factors affecting the distribution range. This was because they were calculated based on the important values of wetland herbs in the zone. Explore the relationship between plant diversity and environmental factors, to further determine the main environmental factors for the distribution range of wetland herbs.

Fig.12 was the RDA between Shannon-Wiener index(SW), marglef index(M) and species richness(S) and environmental factors, and the distribution range of wetland herbs. After the Monte Carlo test, except for the influence of the distribution range of wetland herbs, SW and M were mainly affected by SMO, STP, SSC, and soil pH ; S was mainly affected by SOM, STN, SSC, soil pH, and also affected by AAT and AAR.

\section{Discussion}

Combined with the natural environmental characteristics of the above four lakes (Fig. 7), it can be seen that although the four lakes belong to the Tibet Plateau, they had obvious differences in elevation, AAR, AAR, and soil nutrient content. The AAT of the BK1 sampling line was $6.3^{\circ} \mathrm{C}$ higher than that of SK2. The SMO, SOM, STC, STN, and STP content of BK1 were 5.13, 4.11, 6.80, 41.88, 3.81 times of SC2, respectively. But, the distribution range of wetland herbs on the BK1 with the lowest elevation and the best climatic conditions was not the widest. In the previous study, we investigated the distribution range of lake-terrestrial ecotone wetland herbs in the lakes in the lower Yangtze Plain, which was basically in the same latitude range as the above 4 lakes(showen in Table 2). The wet herbaceous species richness and community diversity index of lake-terrestrial ecotone in the lower Yangtze plain were significantly higher than those of lakes in Tibet, however, the high-density population distribution, agricultural planting, and road construction invaded the plants' growth area, resulting in a smaller distribution range[56]. As the 
altitude increases, human activities decrease[57], and the distribution range of wetland herbs becomes larger. This also explained why the distribution range of YT1 and NT1 wetland herbs was slightly higher than that of BK1. Besides, in our investigation, we found that some wet plants such as Potentilla anserina L.,Duchesnea indica,Plantago asiatica L. were distributed in the lower Yangtze Plain and Baksum Lake, Namtso, and Yamdroktso at the same time. Some studies suggest that as the climate warms, highaltitude areas may become shelters for plants[58].

Table 2 Comparison of latitude and longitude, plant distribution range and characteristics of lakes on the lower Yangtze Plain (Changtan Reservoir, Taihu Lake, Xiazhu Lake) and the Qinghai-Tibet Plateau lakes (Baksum Lake,Yamdroktso,Namtso,Siling Co)

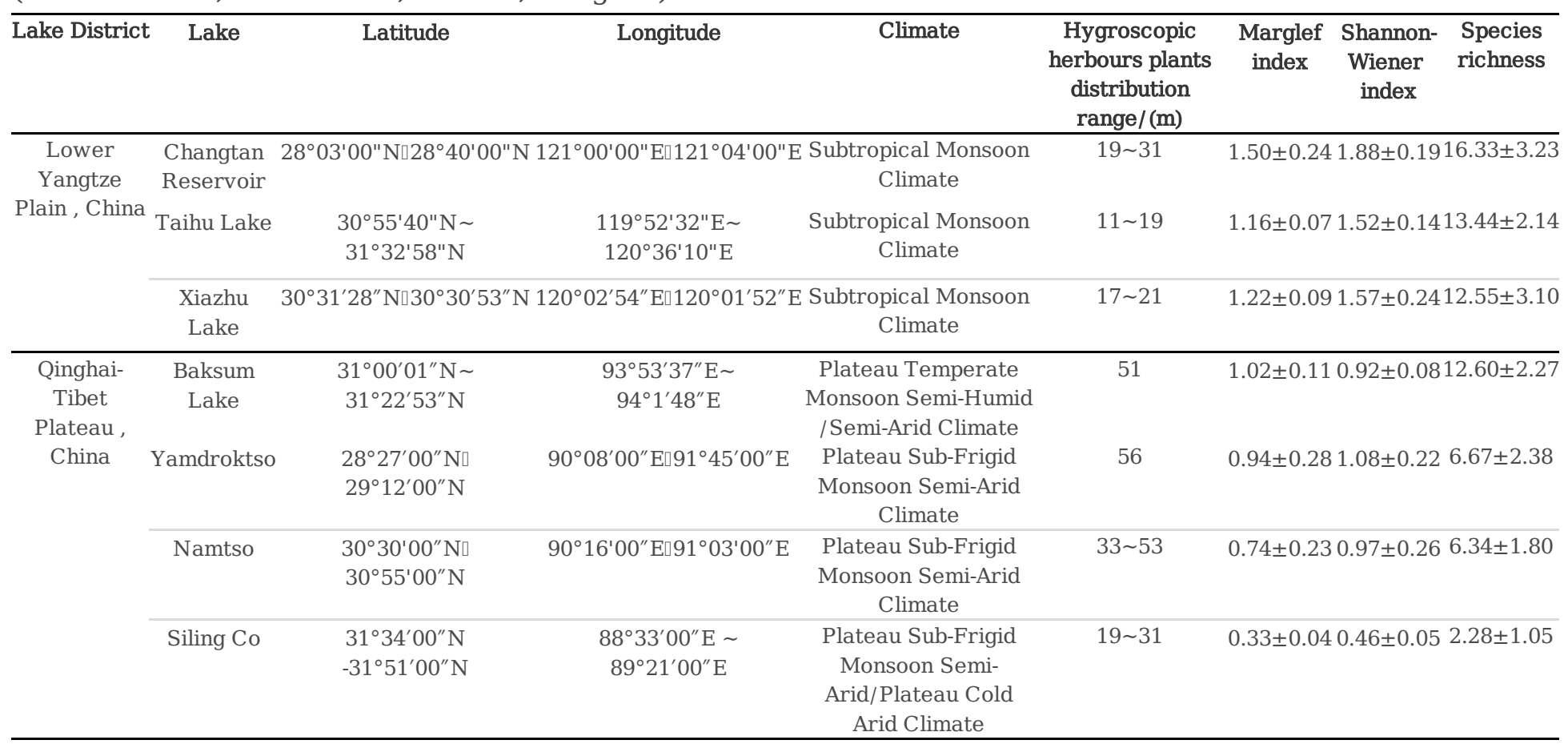

The four lakes on the Tibet Plateau are far apart in space, and the species and quantities of wet plants distributed within each sampling line were quite different(Fig. 5). The NT2, SC1, and SC2 sampling lines were located in northern Tibet, belong to the arid area desertification ecosystem. It is arid and high-cold all year round, with extremely low soil nutrient content, low plant community species richness, and single community structure[59]. PCA and RDA results showed that water and heat conditions, soil nutrients were the main factors restricting the growth and distribution of plants in drought and alpine regions[60-62]. Wang[63] found that higher SMO and STN in alpine regions promoted the increase of plant biomass and richness and vice versa.

PCA showed that the Shannon-Wiener index and Marglef index are the most important factors influencing the distribution range of wetland herbs. Therefore, to determine the main influencing factors of the distribution range of lake-terrestrial ecotone wet herbs, it is also necessary to explore the environmental factors affecting the Shannon-Wiener index, Marglef index, and species richness index.

The distribution range of wetland herbs, $\mathrm{M}, \mathrm{SW}$, and $\mathrm{S}$ were significantly negatively correlated with soil pH and salinity, indicated that the number of species and community richness in the sampling line decreased with the increase of soil pH and salinity. Soil salinity was stressful to the growth of wet herbs[64]. This 
may be due to the decrease in the utilization of soil nutrients by wetland herbs as the soil salinity increases[65-66]. As shown in PCA, soil pH and SSC were significantly negatively correlated with SOM, STC, STN, and STP content, and SSC was significantly negatively correlated with SOM and STP. High salinity and alkalinity restricted the growth of wet herbs. As shown in Fig. 10, the wetland herbs distributed in SC1 2 are Suaeda glauca and Achnatherum splendens, both had high tolerance to salinity and alkalinity[67-68]. This also showed that different wet herb species have different adaptability to soil $\mathrm{pH}$ and SSC[69]. Soil pH and SSC were important influences on the distribution range of lake-terrestrial ecotone wetland herbs in the four lakes.

Except for Baksum Lake, Yamdroktso, Namtso, and Siling Co belong to relatively arid alpine regions. The composition, richness, and diversity of plants in the ecosystem are mainly restricted by soil moisture and salinity. The heterogeneity of soil moisture strongly affected the distribution of plants[70]. The results of RDA and vegetation distribution showed that higher soil moisture was more conducive to the growth of wetland herbs, which was consistent with the results of Zhao[71] studies on the prominent limiting factors for the growth of desert plants in arid areas. Therefore, soil water content was one of the main factors affecting the distribution range of lake-terrestrial ecotone wetland herbs in the four lakes.

Pearson correlation analysis showed that the correlation coefficients between SMO, soil pH, SOM, STP, SSC content, and the distribution range of wetland herbs were $0.951(P<0.01),-0.831,-0.902,0.821,0.905$ $(P<0.05)$. Besides, the correlation between SMO, pH, SSC, SOM, and STP content was significant. Fang[72] researched on the lake wetland of Aibi Lake in the arid area showed that The SMO of lakeside wetlands in alpine and arid areas was significantly affected by soil type, topography, climate, and other structural factors. Soil pH and nutrient content were significantly affected by SMO.

Lake-terrestrial ecotone, as a transition zone between water ecosystems and terrestrial ecosystems, was an important biological transition zone for the exchange of energy, material, and information between water and terrestrial ecosystems[73]. The distribution range of wetland herbs reflected the impact of lakes on the terrestrial environment. Due to the distribution range of lake-terrestrial ecotone vegetation community depended on the degree of tolerance of dominant species to major environmental stress factors[74], and water is an important factor that affects the ecological adaptation of lake-terrestrial ecotone plants and restricts the growth and distribution of plants[75]. Small differences in soil moisture content will cause significant differences in the germination of wetland plant seeds, which will affect the distribution of wetland plants communities[76]. There were significant differences in climate among Baksum Lake, Yambdroktso, Namtso, and Siling Co, leading to differences in soil pH, water content, and nutrient content. These conditions made the distribution of lake-terrestrial ecotone wetland herbs in the Tibet lake area affected by many factors. Therefore, from a macro perspective, it was due to the differences in climatic conditions, determined the distribution range of wetland herbs in the Tibetan lake area; from the perspective of plant growth, soil moisture content was the most important factor affecting the distribution range of wetland herbs.

\section{Conclusion}


MSWT was used to delimit the distribution range of lake-terrestrial ecotone wetland herbs in Baskum Lake (BK1), Yamdroktso (YT1), Namtso (NT1 2), and Siling Co (SL1 2) respectively 51m, $56 \mathrm{~m}, 33 \sim 53$ $\mathrm{m}, 19 \sim 31 \mathrm{~m}$. The delimitation results were consistent with the growth boundary of wetland herbs in the field survey. A total of 33 wetland herbs were investigated in the above-mentioned sampling lines, belonging to 21 families. There were more wetland herbs in the Rosaceae, Ranunculaceae, and Polygonaceae. Combined with field investigation and DCA analysis, wetland herbs are mostly distributed in BK1. Used PCA to analyze the environmental factors driving the sdistribution range of wetland herbs. RDA was used to analyze the response relationship among the number of wet herbaceous plant communities, Shannon-Wiener index, Marglef index, and environmental factors further determined the main factors affecting the distribution range of wetland herbs. The results showed that SMO, pH, SSC, and soil nutrient content were all-important environmental factors that affect the distribution range of the lake-terrestrial ecotone wetland herbs in the four lakes, however, the SMO was the most important factor affecting the distribution range of wetland herbs.

\section{Abbreviations}

MSWT:moving split-window technology;SED:squared euclidean distance;IV:important value;DCA:detrended correspond analysis;PCA:principal component analysis;RDA:redundancy analysis;BK:Baksum lake;NT:Namtso;YT:Yamdroktso;SC: Siling Co;AAR:annual average rainfall;AAT:annual average temperature;SCC:soil salt content;SMO:soil moisture;SOM:soil organic matter;STC:soil total carbon;STN:soil total nitrogen;STP:soil total phosphorus;SMT:the standards,measurements and testing programme method;SW:shannon-wiener index;M:marglef index;S:species richness.

\section{Declarations}

\section{Acknowledgements:}

Thanks to Li Fuxing and Wang Junli of the Shanghai Academy of Agricultural Sciences for overcoming physical discomfort caused by high altitude hypoxia, gave guidance and help on the filed investigation. We further thank assistance provided by Department of Ecological Environment of Tibet Autonomous Region in this study This work was sup-ported by a grant to Barger from the USDA National Research Initiative Managed Ecosystems Program (Proposal No. 2008-00776)

\section{Author contributions}

PZ designed this study based on the theory proposed by $C Y$ and $C L . P Z, H W, W W$, and YZ participated in the field survey and sampling, PZ analyzed the data and drafted the manuscript, and all authors contributed to the final version.

\section{Funding}


National Major Science and Technology Program for Water Pollution Control and Treatment, China ( No.2012ZX07101-009).

\section{Availability of data and materials}

Not applicable.

\section{Ethics approval and consent to participate}

Not applicable.

\section{Consent for publication}

Not applicable.

\section{Competing interests}

The authors declare that they have no competing interest.

\section{Author details}

${ }^{1}$ State Key Laboratory of Environmental Criteria and Risk Assessment, State Environmental Protection Key Laboratory for Lake Pollution Control, National Engineering Laboratory for Lake Pollution Control and Ecological Restoration, Chinese Research Academy of Environmental Sciences, Beijing 100012, China; ${ }^{2}$ Chunliang Oil Production Plant, Shengli Oilfield Company, Sinopec; ${ }^{3}$ College of Life and Environmental Science, Wenzhou University, Wenzhou 325035, China.

\section{References}

[1]Ye C, Li C, Deng T. (2015). Structures and ecological functions of lake littoral zones. Research of Environmental Sciences 28:171-181. https://doi.org/10.13198/j.issn.1001-6929.2015.02.02

[2]Ye C, Li C, Chen X, Jiao X, Lu S. (2012). Classification and ecological restoration modes for the littoral zone of Lake Taihu. Journal of Lake Sciences 24:822-828. https://doi.org/10.18307/2012.0603

[3]Makarewicz JC, Lewis TW, Pennuto CM, Atkinson JF, Edwards WJ, Boyer GL, Howell ET, Thomas G. (2012). Physical and chemical characteristics of the nearshore zone of Lake Ontario. Journal of Great Lakes Research 38:21-31. https://doi.org/10.1016/j.jglr.2011.11.013

[4]Bettez ND,Groffman PM. (2012). Denitrification potential in stormwater control structures and natural riparian zones in an urban landscape. Environmental science \& technology 46:10909-10917.

https://doi.org/10.1021/es301409z 
[5]Nishihiro J, Washitani I. (2007). Restoration of lakeshore vegetation using sediment seed banks; studies and practices in Lake Kasumigaura, Japan. Global Environmental Research 11:171-177.

[6]Chen J, Kong D, Fan Y, Zhao L, Li J, Yang F. (2012). Restoration project of embankment and substrata in Dianchi's lakeshore. Environmental Science \& Technology (China) 35:157-179. https://doi.org/10.3969/j.issn.1003-6504.2012.06.034

[7]Wang H, Song C , Liu X, Li K. (2012). Lakeshore overview of lake chaohu and ecological rehabilitation schemes for shoreline and littoral zones. Resources and Environment in the Yangtze Basin 21:63-64.

[8]Chen F, Lu S, Hu X, He Q, Feng C, Xu Q, Chen N, Ngo H, Guo H. (2019). Multi-dimensional habitat vegetation restoration mode for lake riparian zone, Taihu, China. Ecological Engineering 134:56-64. https://doi.org/10.1016/j.ecoleng.2019.05.002

[9]Yuan X, Zhang Y, Liu H, Xiong S, Li B, Deng W. (2013). The littoral zone in the Three Gorges Reservoir, China: challenges and opportunities. Environmental Science and Pollution Research 20:7092-7102. https://doi.org/10.1007/s11356-012-1404-0

[10]Tao Y, Wu G, Zhang Y. (2017). Dune-scale distribution pattern of herbaceous plants and their relationship with environmental factors in a saline-alkali desert in Central Asia. Science of the Total Environment 576:473-480. https://doi.org/10.1016/j.scitotenv.2016.10.102

[11]Liu Y, Ren W, Shu T, Xie C, Jiang J, Yang S. (2015). Current status and the long-term change of riparian vegetation in last fifty years of Lake Honghu. Resources and Environment in the Yangtze Basin 24:38-45.

[12]Tölgyesi C, Körmöczi L. (2012). Structural changes of a Pannonian grassland plant community in relation to the decrease of water availability. Acta Botanica Hungarica 54:413-431.

https://doi.org/10.1556/ABot.54.2012.3-4.17

[13]Sun R, Chen W,Song X. Luo Y, Liu L. (2019). Distribution characteristics and edge effect of soil water and salt in silvopastoral system of the Yellow River Delta, China. Chinese Journal of Applied Ecology 30:2549-2557. https://doi.org/10.13287/j.1001-9332.201908.003

[14]Hufkens K, Scheunders P, Ceulemans R. (2009). Ecotones in vegetation ecology: methodologies and definitions revisited. Ecological Research 24:977-986. https://doi.org/10.1007/s11284-009-0584-7

[15]Körmöczi L, Bátori Z, Erdős L, Tölgyesi C, Zalatnai M, Varró C. (2016). The role of randomization tests in vegetation boundary detection with moving split-window analysis. Journal of Vegetation Science 27:1288-1296. https://doi.org/10.1111/jvs.12439

[16]Ou X, Liu X, Zhang Z, Wang W, Shi W, Fang X. (2011). Advances in ecotone width determination and its impact factors. Ecological Science 30:88-96. https://doi.org/10.3969/j.issn.1008-8873.2011.01.016 
[17]Wang T, Ou X, Zhang Z, Liu X, Wang L, Sun Z., He B, Li F. (2012). Measurement of ecotone width between agro-ecosystem and forest ecosystems after grain for green program. Journal of Yunnan University-Natural Sciences Edition 34:604-612.

[18]Xiong D, Ou X, Huang W, Yang J, Wang T, Guo J, Zhang Z, (2014). Measurement of eco-tone width between agro-forest ecosystems based on soil nutrients. Ecological Science 33:594-602. https://doi.org/10.3969/j.issn. 1008-8873.2014.03.030

[19]Su X, Wang Z.(2017). Research on boundary definition and plant community diversity of wetlandgrassland ecotone:a case study:Siertan Wetland in Ningxia. Forest Resources Management, 1:63-69. https://doi.org/10.13466/j.cnki.lyzygl.2017.01.012

[20]Li H, Liu X ,Zhang K, Miao J, Siraj·M.(2016). Definition of wetland-dry grassland ecotone and vegetation stability in the Nanhaizi wetland in Yanchi, Ningxia. Pratacultural Science 33:170-176. https://doi.org/10.11829/j.issn.1001-0629.2016.0462

[21]Li W, Xu Q, Li J, Li SL, Yu Q, Zhang Z.(2017). Quantification of ecotone width of returned forest land from farmland based on specific leaf area. Journal of West China Forestry Science 46:117-121. https://doi.org/10.16473/j.cnki.xblykx1972.2017.01.022

[22]Humphries NE, Queiroz N, Dyer JR, Pade NG, Musyl MK, Schaefer KM, Fuller DW, Brunnschweiler JM, Doyle TK, Houghton JD, Hays GC. (2010). Environmental context explains Lévy and Brownian movement patterns of marine predators. Nature 465:1066-1069. https://doi.org/10.1038/nature09116

[23]Pärn J, Remm K, Mander Ü. (2010). Correspondence of vegetation boundaries to redox barriers in a Northern European moraine plain. Basic and Applied Ecology 11:54-64.

https://doi.org/10.1016/j.baae.2009.08.001

[24]Pandita S, Dutt HC. (2020). Land use induced blurring of forest-grassland transition in north-west Himalaya-A case study using Moving Split Window boundary detection technique. Journal of Mountain Science 17:3085-3096.

https://doi.org/10.1007/S11629-019-5513-9

[25]Xie Y, Qiu K, Xu D, Shi X, Qi T, Pott R. (2015). Spatial heterogeneity of soil and vegetation characteristics and soil-vegetation relationships along an ecotone in Southern Mu Us Sandy Land, China. Journal of Soils and Sediments 15:1584-1601. https://doi.org/10.1007/s11368-015-1114-6

[26]Figueiredo FO, Zuquim G, Tuomisto H, Moulatlet GM, Balslev H, Costa FR. (2018). Beyond climate control on species range: the importance of soil data to predict distribution of Amazonian plant species. Journal of Biogeography 45:190-200. https://doi.org/10.1111/jbi.13104

[27]Gong X, Brueck H, Giese KM, Zhang L, Sattelmacher B, Lin S. (2008). Slope aspect has effects on productivity and species composition of hilly grassland in the Xilin River Basin, Inner Mongolia, China. 
Journal of arid environments 72:483-493. https://doi.org/10.1016/j.jaridenv.2007.07.001

[28]Torma A, Császár P. (2013). Species richness and composition patterns across trophic levels of true bugs (Heteroptera) in the agricultural landscape of the lower reach of the Tisza River Basin. Journal of Insect Conservation 17:35-51. https://doi.org/10.1007/s10841-012-9484-1

[29]Calhoun AJ, Mushet DM, Bell KP, Boix D, Fitzsimons JA, Isselin-Nondedeu F. (2017). Temporary wetla;nds: challenges and solutions to conserving a 'disappearing'ecosystem. Biological conservation 211: pp.3-11. https://doi.org/10.1016/j.biocon.2016.11.024

[30]Petersen JE, Brandt EC, Grossman JJ, Allen GA, Benzing DH. (2015). A controlled experiment to assess relationships between plant diversity, ecosystem function and planting treatment over a nine year period in constructed freshwater wetlands. Ecological Engineering 82:531-541.

https://doi.org/10.1016/j.ecoleng.2015.05.002

[31]Wang S, Dou H, editor.(1998). Records of China Lake.Beijing: Science Press Beijing.

[32]Lin Q, Xu L, Hou J, Liu Z, Jeppesen E, Han B. (2017). Responses of trophic structure and zooplankton community to salinity and temperature in Tibetan lakes: Implication for the effect of climate warming. Water research 124:618-629. https://doi.org/10.1016/j.watres.2017.07.078

[33]Zhao W, Xiong D, Wen F, Wang X. (2020). Lake area monitoring based on land surface temperature in the Tibetan Plateau from 2000 to 2018. Environmental Research Letters 15:084033. https://doi.org/10.1088/1748-9326/ab9b41

[34]Huang X, Sillanpää M, Gjessing ET, Peräniemi S, Vogt RD. 2010. Environmental impact of mining activities on the surface water quality in Tibet: Gyama valley. Science of the total environment 408:41774184.

[35]Wang X. (2014). Sustainable development in tibet requires control of agricultural nonpoint pollution. Environmental Science \& Technology 48: 8944-8945. https://doi.org/10.1016/j.scitotenv.2010.05.015

[36]Zhang H, Wang Z, Zhang Y, Hu Z. (2012). The effects of the Qinghai-Tibet railway on heavy metals enrichment in soils. Science of the Total Environment 439:240-248.

https://doi.org/10.1016/j.scitotenv.2012.09.027

[37]Tong K, Su F, Li C. (2020). Modeling of Water Fluxes and Budget in Nam Co Basin during 1979-2013. Journal of Hydrometeorology 21:829-844. https://doi.org/10.1175/JHM-D-19-0135.1

[38]Li D, Li Y, Ma B, Dong G, Wang L, Zhao J. (2009). Lake-level fluctuations since the Last Glaciation in Selin Co (lake), Central Tibet, investigated using optically stimulated luminescence dating of beach ridges. Environmental Research Letters 4:045204. https://doi.org/10.1088/1748-9326/4/4/045204 
[39]Jia X, Wang D, Liu F, Dai Q. (2020). Evaluation of highway construction impact on ecological environment of Qinghai-Tibet Plateau. Environmental Engineering \& Management Journal (EEMJ), 19: 1157-1166.

[40]Wu Y, Wang S, Ni Z, Li H, May L, Pu J. (2021). Emerging water pollution in the world's least disturbed lakes on Qinghai-Tibetan Plateau. Environmental Pollution 272:116032.

https://doi.org/10.1016/j.envpol.2020.116032

[41]Li K, Liu X, Herzschuh U, Wang Y. (2016). Rapid climate fluctuations over the past millennium: evidence from a lacustrine record of Basomtso Lake, southeastern Tibetan Plateau. Scientific reports 6:19. https://doi.org/10.1038/srep24806

[42]Zhang X, Sun R, Zhu L. (2012). Lake water in the Yamzhog Yumco Basin in South Tibetan region: quality and evaluation. Journal of Glaciology and Geocryology 34:950-958.

https://doi.org/10.1007/s11783-011-0280-z

[43]Feng J, Chen F, Hu H. (2017). Isotopic study of the source and cycle of sulfur in the Yamdrok Tso basin, Southern Tibet, China. Applied Geochemistry 85:61-72. https://doi.org/10.1016/j.apgeochem.2017.09.005

[44]Yang K, Wang J, Lei Y, Chen Y, Zhu L, Ding B, Qin J. (2016). Quantifying evaporation and its decadal change for Lake Nam Co, central Tibetan Plateau. Journal of Geophysical Research: Atmospheres 121:7578-7591. https://doi.org/10.1002/2015JD024523

[45]Wang J, Zhu L, Daut G, Ju J, Lin X, Wang Y, Zhen X. (2009). Investigation of bathymetry and water quality of Lake Nam Co, the largest lake on the central Tibetan Plateau, China. Limnology 10:149-158. https://doi.org/10.1007/s10201-009-0266-8

[46]Deng Y, Liu P, Conrad R. (2019). Effect of temperature on the microbial community responsible for methane production in alkaline NamCo wetland soil. Soil Biology and Biochemistry 132:69-79. https://doi.org/10.1016/j.soilbio.2019.01.024

[47]Kou Q, Lin X, Wang J, Yu S, Kai J, Laug A, Zhu L. (2021). Spatial distribution of n-alkanes in surface sediments of Selin Co Lake, central Tibetan Plateau, China. Journal of Paleolimnology 65:53-67. https://doi.org/10.1007/s10933-020-00148-8

[48]Guo Y, Zhang Y, Ma N, Xu J, Zhang T. (2019). Long-term changes in evaporation over Siling Co Lake on the Tibetan Plateau and its impact on recent rapid lake expansion. Atmospheric research 216:141-150. https://doi.org/10.1016/j.atmosres.2018.10.006

[49]Chen Y, (2001). Hydrographic features of Serling Co, North Tibetan Plateau. Journal of Lake Sciences 13:21-28. https://doi.org/10.18307/20010104 
[50]Erdős L, Zalatnai M, Bátori Z, Körmöczi L. (2014). Transitions between community complexes: a case study analysing gradients through mountain ridges in South Hungary. Acta Botanica Croatica 73:63-77. https://doi.org/10.2478/botcro-2013-0009

[51]Dale MR, Fortin MJ. (2014). Spatial analysis: a guide for ecologists. Cambridge :Cambridge University Press.425p.

[52]Zhang B. (2013). Study on Distribution characteristics and flux of organic matter, nitrogen and phosphorus in the soil of wlfz of Three Gorges Reservoir. Chongqing: Chongqing University.124p.

[53]Choesin D, Boerner REJ. (2002). Vegetation boundary detection: a comparison of two approaches applied to field data. Plant Ecology 158:85-96. https://doi.org/10.1023/A:1014720508155

[54]Kröger R, Khomo LM, Levick S, Rogers KH. (2009). Moving window analysis and riparian boundary delineation on the Northern Plains of Kruger National Park, South Africa. Acta Oecologica 35:573-580. https://doi.org/10.1016/j.actao.2009.05.007

[55]Lantman IMVS, Hertzog LR, Vandegehuchte ML, Martel A, Verheyen K, Lens L, Bonte D. (2020). Forest edges, tree diversity and tree identity change leaf miner diversity in a temperate forest. Insect Conservation and Diversity 13:10-22. https://doi.org/10.1111/icad.12358

[56]Zheng P, Shang X, Ye C, Li C, Zheng X, Dai W, Wei W. (2021). Delimiting the radiant belt toward land of lake-terrestrial ecotone with natural-wetland type. Research of Environmental Sciences 34:953-963. https://doi.org/10.13198/j.issn.1001-6929.2020.12.29

[57]Nogués-Bravo D, Araújo MB, Romdal T, Rahbek C. (2008). Scale effects and human impact on the elevational species richness gradients. Nature 453:216-219. https://doi.org/10.1038/nature06812

[58]Shimono A, Zhou H, Shen H, Hirota M, Ohtsuka T, Tang Y. (2010). Patterns of plant diversity at high altitudes on the Qinghai-Tibetan Plateau. Journal of Plant Ecology 3:1-7. https://doi.org/10.1093/jpe/rtq002

[59]Huo J, Liu W, Liu J, Li H, Xu Y, Maria·N. (2017) Driving forces of desert plant characteristics in a desert oasis transitional zone in Driving forces of desert plant characteristics in a desert oasis transitional zone in FuKang, Xinjiang, China. Acta Ecologica Sinica 37:1-10. https://doi.org/10.5846/stxb201610282199

[59]Long T, Wang J, Li J, Feng Y, Wu B, Lu Q. (2017). Plant diversity and its environmental explanation in gobi district of northern Qinghai-Tibet Plateau, northwestern China. Journal of Beijing Forestry University 39:17-24. https://doi.org/10.13332/j.1000-1522.20170395

[61]Liu L. (2016) The relationship between plant diversity and climate factors in different grassland types of Xinjiang .Urumqi: Xinjiang Agricultural University. 68p. 
[62]Fayech D, Tarhouni J. (2020). Climate variability and its effect on normalized difference vegetation index (NDVI) using remote sensing in semi-arid area. Modeling Earth Systems and Environment, in press. https://doi.org/10.1007/S40808-020-00896-6

[63]Wang Z, Yang G, Yi S, Chen S, Wu Z, Guan J, Zhao C, Zhao Q, Ye B. (2012). Effects of environmental factors on the distribution of plant communities in a semi-arid region of the Qinghai-Tibet Plateau. Ecological Research 27:667-675. https://doi.org/10.1007/s11284-012-0951-7

[64]Qiao B, Huang W, He T, Su Z, Feng Y. (2018). Analysis on the diversity of halophyte plant community and soil salinity in beach-wetland of Zhen-Lake of Ningxia. Acta Botanica Boreali-Occidentalia Sinica 38:324-331.

https://doi.org/10.7606/j.issn.1000-4025.2018.02.0324

[65]Tian L, Zhao L, Wu X, Fang H, Zhao Y, Yue G, Liu G, Chen H. (2017). Vertical patterns and controls of soil nutrients in alpine grassland: Implications for nutrient uptake. Science of the Total Environment 607:855-864. https://doi.org/10.1016/j.scitotenv.2017.07.080

[66]lqbal T. (2018). Rice straw amendment ameliorates harmful effect of salinity and increases nitrogen availability in a saline paddy soil. Journal of the Saudi Society of Agricultural Sciences, 17:445-453. https://doi.org/10.1016/j.jssas.2016.11.002

[67]Kou X, Li J, Liu H, Li B, Yu X, Cao X, Liu D, Wen L, Zhuo Y, Wang L. (2020). Characteristics of bacterial biodiversity and community structure in non-rhizosphere soils along zonal distribution of plants within littoral wetlands in inner Mongolia, China. Global Ecology and Conservation, in press. https://doi.org/10.1016/j.gecco.2020.e01310

[68]Li J, Hussain T, Feng X, Guo K, Chen H, Yang C, Liu X. (2019). Comparative study on the resistance of Suaeda glauca and Suaeda salsa to drought, salt, and alkali stresses. Ecological Engineering 140:105593. https://doi.org/10.1016/j.ecoleng.2019.105593

[69]Zhao M, Zhao R, Zhang L, Zhao H, Zhou Y. (2019). Plant diversity and its relationship with soil factors in the middle reaches of the Heihe River based on the soil salinity gradient. Acta Ecologica Sinica 39:4116-4126. https://doi.org/10.5846/stxb201806231386

[70]Närhi P, Middleton M, Hyvönen E, Piekkari M, Sutinen R. (2010). Central boreal mire plant communities along soil nutrient potential and water content gradients. Plant and soil 331:257-264. https://doi.org/10.1007/s11104-009-0250-4

[71]Zhao X, He X, Yang X, Zhang X, Lv G. (2017). Effects of soil moisture and salt on desert plant biodiversity in Ebinur Lake Basin of Xinjiang, China. Journal of Arid Land Resources and Environment 31:76-82. https://doi.org/10.13448/j.cnki.jalre.2017.182 
[72]Fang L, Li Y, Li F, Zhu HQ . (2019). Analysis of spatial variation of soil moisture-salinity-nutrient in Ebinur Lake wetlands, China. Journal of Agro-Environment Science 38:157-167.

https://doi.org/10.11654/jaes.2018-0632

[73]Osborne LL, Kovacic DA. (1993). Riparian vegetated buffer strips in water-quality restoration and stream management. Freshwater biology, 29:243-258. https://doi.org/10.1111/j.1365-

2427.1993.tb00761.x

[74]Casanova MT, Brock MA. (2000). How do depth, duration and frequency of flooding influence the establishment of wetland plant communities?. Plant Ecology 147:237-250.

https://doi.org/10.1023/A:1009875226637

[75]Fu B, Wang Y, Xu P, Wang D. (2009). Changes in overland flow and sediment during simulated rainfall events on cropland in hilly areas of the Sichuan Basin, China. Progress in Natural Science 19:1613-1618. https://doi.org/10.1016/j.pnsc.2009.07.001

[76]Shen H, Tang Y, Washitani I. (2009). Ecological responses of Primula nutans to centimeter-scale topographic and environmental variability in an alpine wetland. Ecological research 24:75-81. https://doi.org/10.1007/s11284-008-0483-3

\section{Figures}

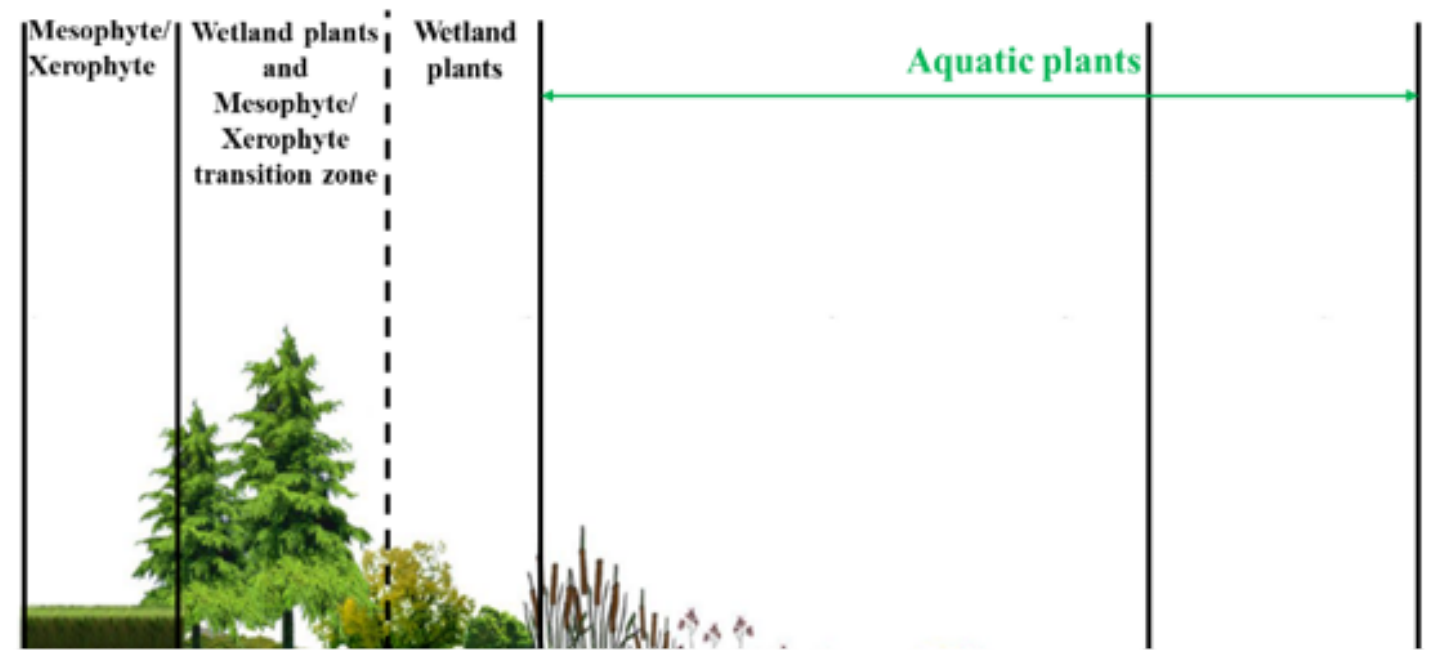

Highwater line 
Spatial structure of lake-terrestrial ecotone with natural-wetland type[1]

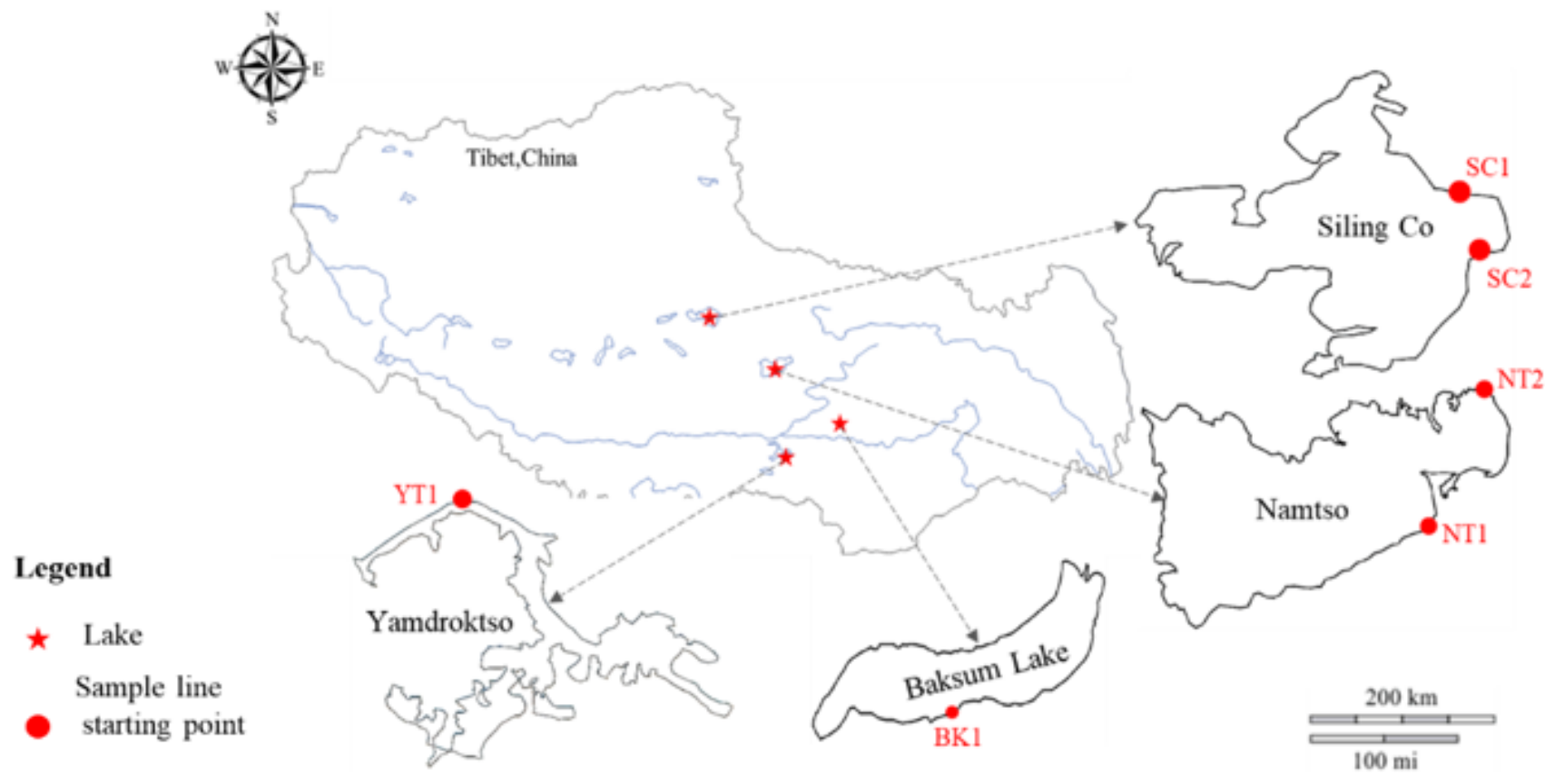

\section{Figure 2}

Schematic of setting the starting point of the sample line

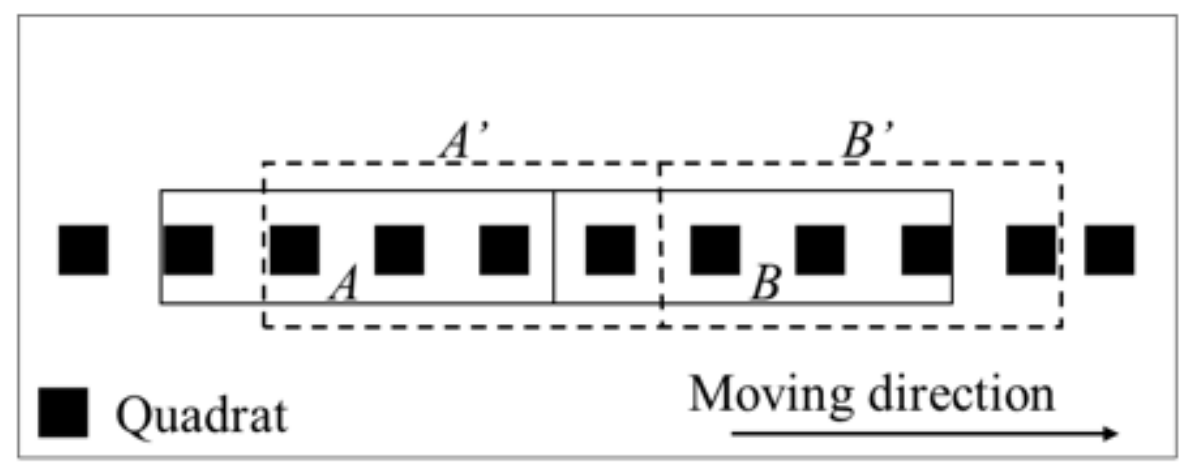

Figure 3

Schematic diagram of MSWT[51] 


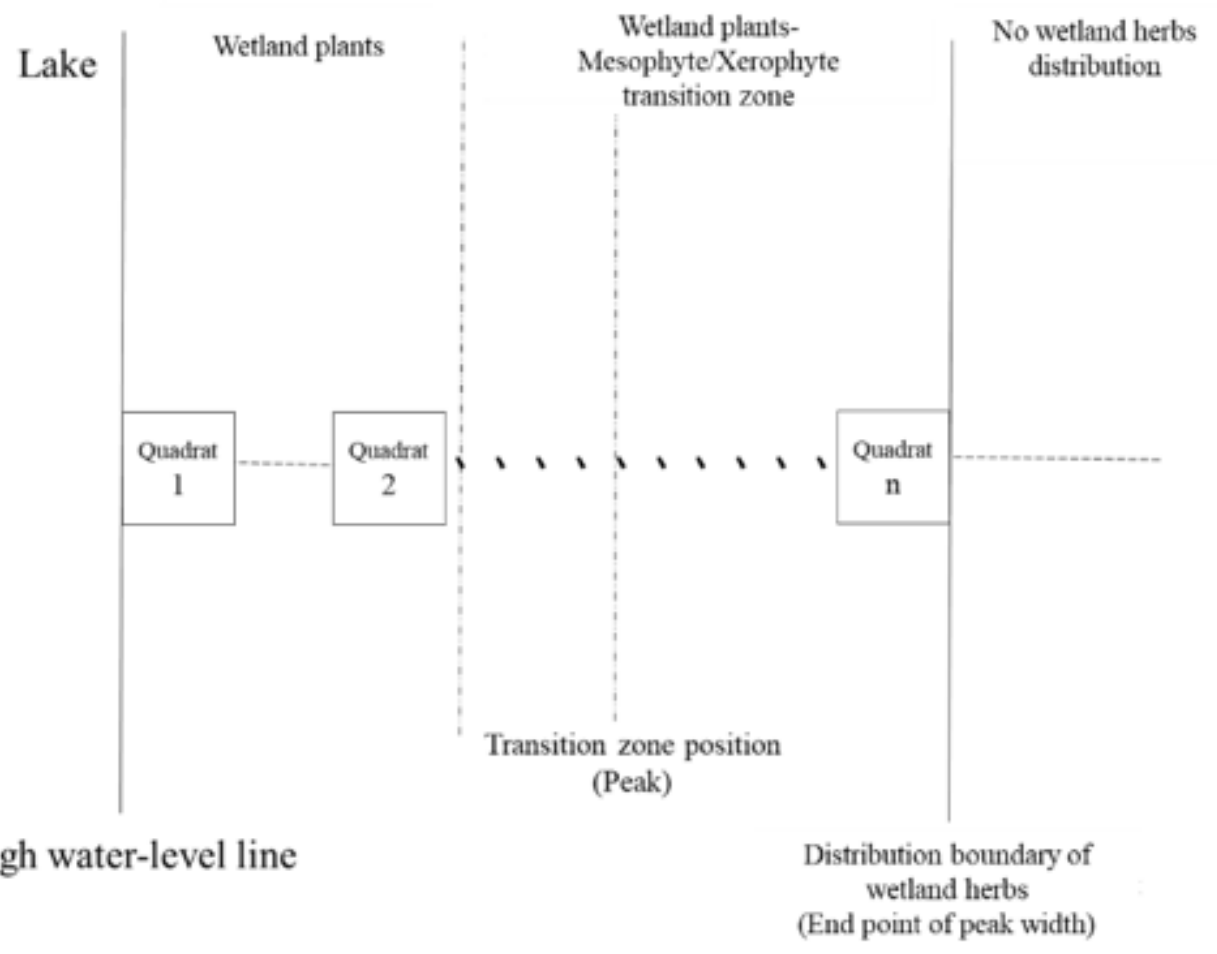

\section{Figure 4}

Schematic diagram of sample square setting
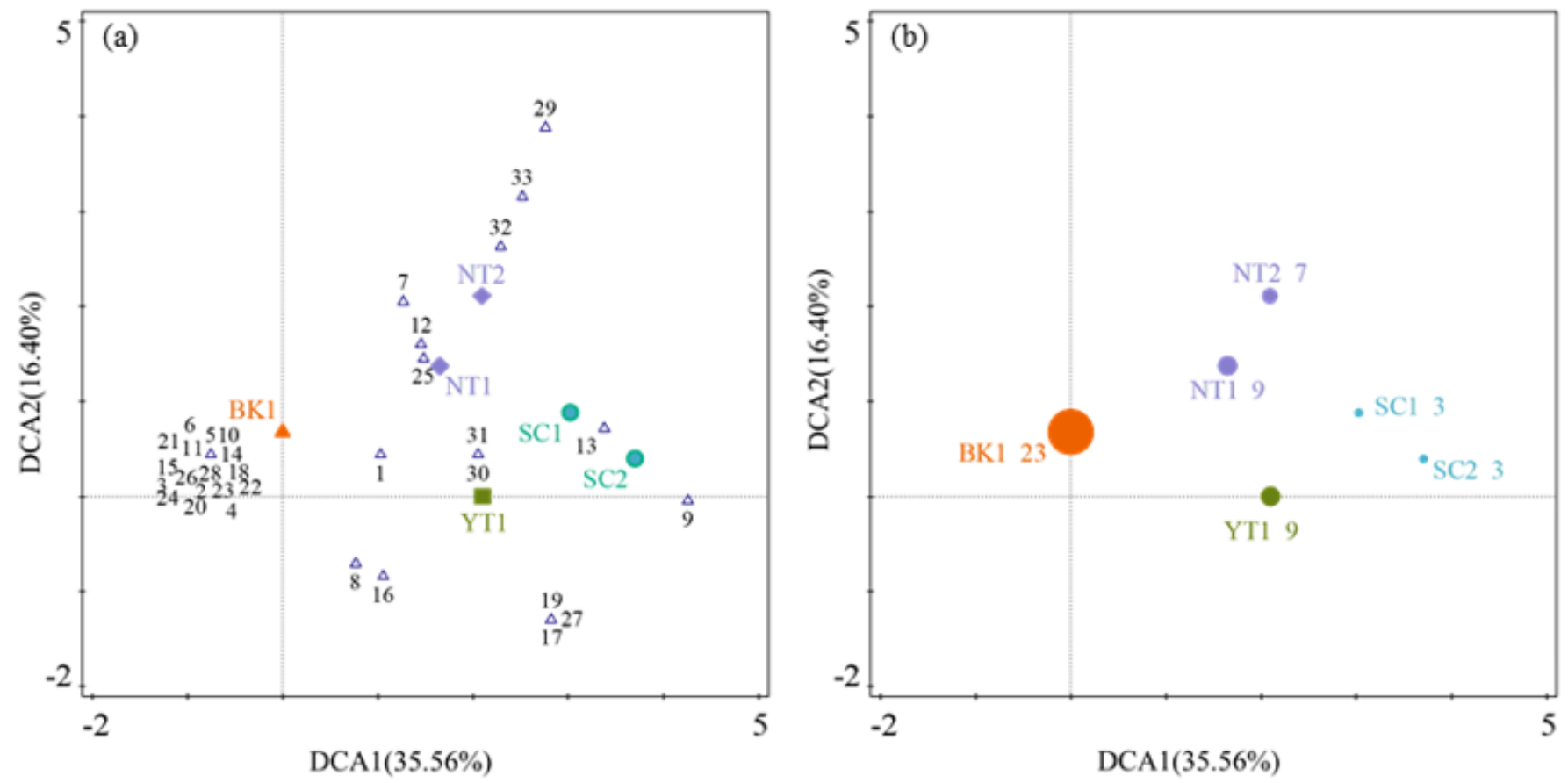

Figure 5

(a) species of wetland herbs,(b) numbers of species distributed in BK1, YT1, NT1 2, SC1 2(DCA) 
Figure 6

Numerical value of Species,Shannon-Wiener,Marglef,Coverage of each sample line
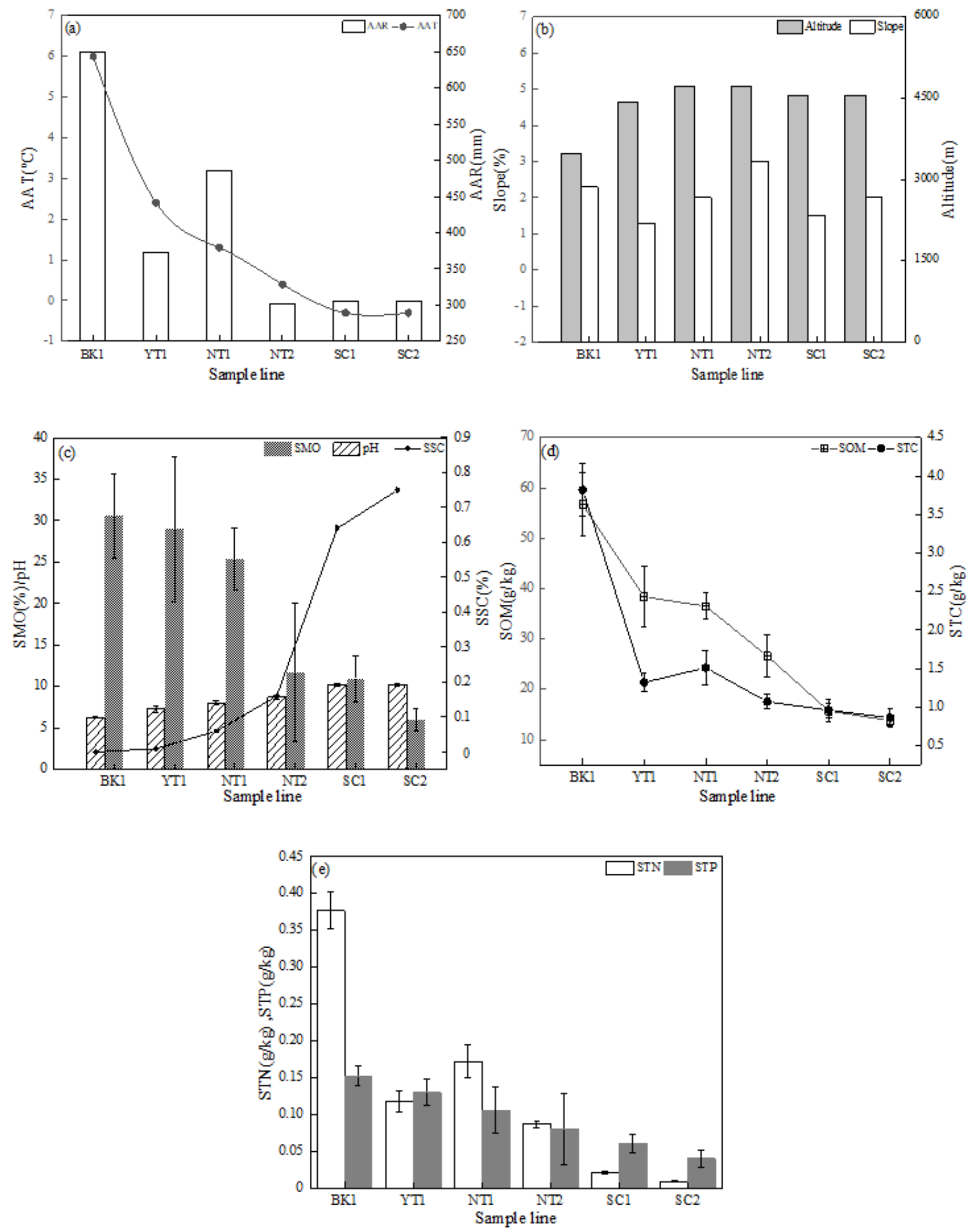

Figure 7 
(a)AAT,AAR,(b)Altitude,Slope,(c)SMO,pH,SSC(d)OM,TC,(e)STN,STP of each sampling line

\section{Figure 8}

(a) SED(IV) peak value under the different window width of (BK1),(b) optimal window width(n=4) for BK1

\section{Figure 9}

(a) (e):SED(IV) peak value under the suitable window of YT1,NT1,NT2,SC1,SC2.

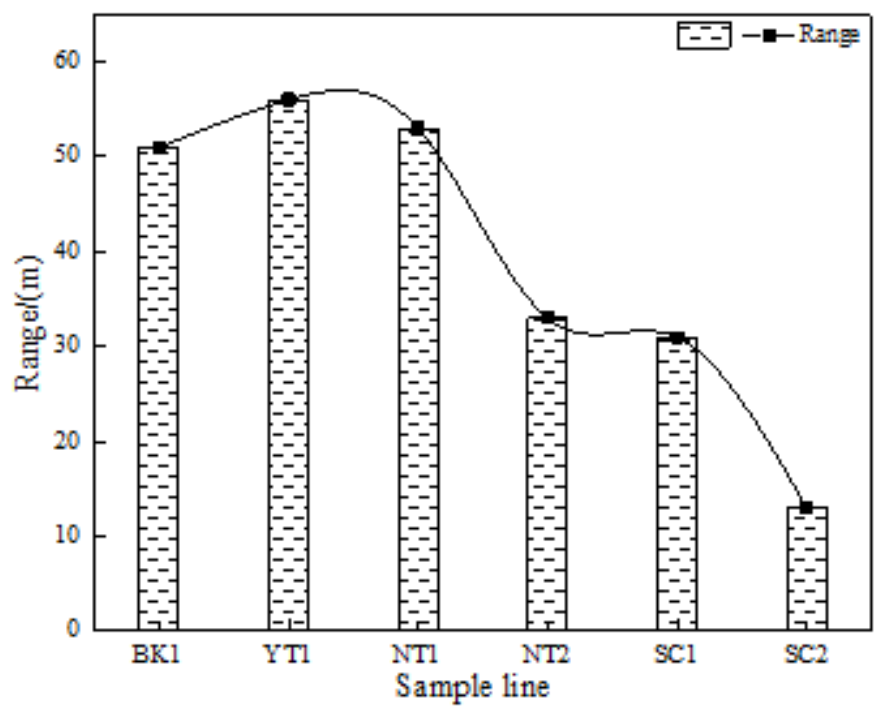

Figure 10

Variation trend of the distribution range of wetland herbs in lake-terrestrial ecotone

Figure 11

Principal component analysis of each factor(PCA)

Figure 12

RDA of species, Shannon-Wiener, Marglef-environmental factors 